\title{
Evaluation of Antifungal Activity of Some Plant Extractives
}

\author{
E. S. J. NIDIRY* \\ ICAR-Indian Institute of Horticultural Research, Bengaluru, Karnataka 560089, India
}

\section{Nidiry: Antifungal activity of plant extractives}

\begin{abstract}
In vitro antifungal activity of thirty two extractives of seven plants obtained using hexane, ethyl acetate and methanol were tested against the mycelial growth of Colletotrichum gloeosporioides. Among these extractives, ethyl acetate extractives of onion seeds, chilli seeds and chilli pericarps and methanol extractives of chilli seeds and chilli pericarps exhibited more than $20 \%$ mycelial growth inhibition at a concentration of $0.5 \%$ level. Methanol extractives of Solanum viarum berries and ethyl acetate extractive of soybean leaves exhibited more than $20 \%$ mycelial growth inhibition at a concentration of $1.0 \%$ level. Thin layer chromatographic bioautography showed that hexane and ethyl acetate extractives of onion seeds, chilli seeds and chilli pericarps exhibited spore germination inhibition of Cladosporium cucumerinum at a dose of $1.0 \mathrm{mg}$.
\end{abstract}

Key words: Antifungal activity, plant extractives, Colletotrichum gloeosporioides, Cladosporium cucumerinum

Investigations regarding the antifungal activity of plant extractives are important because they give insight into the defence mechanism evolved by plants against the attack of fungal pathogens. Such plant extractives and compounds with antifungal activity can be used against human, animal and plant pathogens and for post-harvest preservation, provided they possess suitable properties and sufficient amounts can be extracted from natural sources. Alternatively, structure elucidation of natural antifungal compounds helps in the synthesis of the compounds per se or analogues with improved physical and biological properties. Quantitative evaluation of such compounds in crop plants can facilitate the screening of plants for the development of resistant varieties.

In this paper the evaluation of thirty-two extractives of plant materials namely onion seeds, onion leaves, Gloriosa superba seeds, Bougainvillea spectabilis (green leaves, white bracts and pink bracts), chilli seeds, chilli pericarps, Solanum viarum berries Albizia amara leaves and soybean leaves obtained using hexane, ethyl acetate and methanol for their antifungal activity against the mycelial growth of Colletotrichum gloeosporioides is being discussed. Evaluation of the extractives of onion seeds, chilli seeds and chilli pericarps against the spore germination of Cladosporium cucumerinum by

*Address for correspondence

E-mail: nidiry@yahoo.co.in

January-February 2022
Thin Layer Chromatography (TLC) bioautography is also being discussed.

The plant materials except soybean leaves were collected from the farms of ICAR-Indian Institute of Horticultural Research (IIHR), Hessaraghatta, Bangalore, India or purchased from the local market. Soybean leaves were obtained from ICAR-Indian Institute of Soybean Research, Indore, Madhya Pradesh, India. The plant materials were dried at $60^{\circ}$ and subsequently powdered.

The powdered plant materials were extracted using a Soxhlet apparatus first with hexane, then with ethyl acetate and finally with methanol. In the case of Gloriosa superba, methanol extraction was done immediately after hexane extraction. The respective extractives were obtained by completely distilling out the solvents on a water bath and were tested for antifungal activity.

Colletotrichum gloeosporioides ITCC 4573 was used for the poisoned food technique and Cladosporium cucumerinum IMI 249540 was used for TLC

\footnotetext{
This is an open access article distributed under the terms of the Creative Commons Attribution-NonCommercial-ShareAlike 3.0 License, which allows others to remix, tweak, and build upon the work non-commercially, as long as the author is credited and the new creations are licensed under the identical terms
}

Accepted 22 February 2022 Revised 24 August 2021 Received 01 March 2020 Indian J Pharm Sci 2022;84(1):224-227 
bioautography. Antifungal activity of hexane, ethyl acetate and methanol extractives was studied by observing the mycelial growth inhibition of Colletotrichum gloeosporioides by poisoned-food technique[1]. Per cent mycelial growth inhibition was calculated using the formula $\mathrm{P}=(\mathrm{C}-\mathrm{T} / \mathrm{C}) \times 100$, where $\mathrm{C}$ is the mycelial diameter of the control and $\mathrm{T}$ that of treated ones, after giving due adjustment of the mycelial diameter of the inoculum. The values given in Table 1 are the average of two replications. For TLC bioautography, conidial suspension of Cladosporium cucumerinum in the nutrient solution suggested by Homan and Fuchs $^{[2]}$.

The results of in vitro antifungal activity of thiry-two extractives of seven plants against the mycelial growth of Colletotrichum gloeosporioides are presented in Table 1. Among these extractives, ethyl acetate extractives of onion seeds, chilli seeds and chilli pericarps and methanol extractives of chilli seeds and chilli pericarps exhibited more than $20 \%$ mycelial

TABLE 1: ANTIFUNGAL ACTIVITY OF PLANT EXTRACTIVES FOR THE MYCELIAL GROWTH INHIBITION OF Colletotrichum gloeosporioides

\begin{tabular}{|c|c|c|c|c|}
\hline Plant & Plant part & $\begin{array}{l}\text { Solvent used for preparation } \\
\text { of extractive }\end{array}$ & Concentration (\%) & $\begin{array}{l}\text { Percent mycelial } \\
\text { growth inhibition }\end{array}$ \\
\hline Onion (Allium cepa) & Seeds & Hexane & 0.5 & 0 \\
\hline Onion (Allium cepa) & Seeds & Ethyl acetate & 0.5 & 22.5 \\
\hline Onion (Allium cepa) & Seeds & Methanol & 0.5 & 10 \\
\hline Onion (Allium cepa) & Leaves & Hexane & 1 & 0 \\
\hline Onion (Allium cepa) & Leaves & Ethyl acetate & 1 & 10 \\
\hline Onion (Allium cepa) & Leaves & Methanol & 1 & 6 \\
\hline Chilli (Capsicum annuum) & Seeds & Hexane & 1 & 0 \\
\hline Chilli (Capsicum annuum) & Seeds & Ethyl acetate & 0.5 & 46.4 \\
\hline Chilli (Capsicum annuum) & Seeds & Ethyl acetate & 1 & 54.6 \\
\hline Chilli (Capsicum annuum) & Seeds & Methanol & 0.5 & 25 \\
\hline Chilli (Capsicum annuum) & Seeds & Methanol & 1 & 38.1 \\
\hline Chilli (Capsicum annuum) & Pericarps & Hexane & 1 & 0 \\
\hline Chilli (Capsicum annuum) & Pericarps & Ethyl acetate & 0.5 & 21.4 \\
\hline Chilli (Capsicum annuum) & Pericarps & Methanol & 0.5 & 20.7 \\
\hline Chilli (Capsicum annuum) & Pericarps & Methanol & 1 & 43.6 \\
\hline Gloriosa superba & Seeds & Hexane & 0.5 & 0 \\
\hline Gloriosa superba & Seeds & Methanol & 0.5 & 0 \\
\hline Bougainville spectabilis & Green leaves & Hexane & 0.5 & 0 \\
\hline Bougainville spectabilis & Green leaves & Ethyl acetate & 0.3 & 10 \\
\hline Bougainville spectabilis & Green leaves & Methanol & 0.5 & 0 \\
\hline Bougainville spectabilis & White bract & Hexane & 0.5 & 0 \\
\hline Bougainville spectabilis & White bract & Ethyl acetate & 0.3 & 7 \\
\hline Bougainville spectabilis & White bract & Methanol & 0.5 & 0 \\
\hline Bougainville spectabilis & Pink bract & Hexane & 0.5 & 0 \\
\hline Bougainville spectabilis & Pink bract & Ethyl acetate & 0.3 & 7 \\
\hline Bougainville spectabilis & Pink bract & Methanol & 0.5 & 0 \\
\hline Solanum viarum & Berries & Hexane & 1 & 0 \\
\hline Solanum viarum & Berries & Ethyl acetate & 1 & 31.2 \\
\hline Solanum viarum & Berries & Methanol & 1 & 31.2 \\
\hline Albizzia amara & Leaves & Hexane & 1 & 0 \\
\hline Albizzia amara & Leaves & Ethyl acetate & 1 & 0 \\
\hline Albizzia amara & Leaves & Methanol & 1 & 0 \\
\hline Soybean (Glycine max) & Leaves & Hexane & 1 & 0 \\
\hline Soybean (Glycine max) & Leaves & Ethyl acetate & 1 & 25 \\
\hline Soybean (Glycine max) & Leaves & Methanol & 1 & 20 \\
\hline
\end{tabular}

Note: Percent mycelial growth inhibition was calculated using the formula $\mathrm{P}=(\mathrm{C}-\mathrm{T} / \mathrm{C}) \times 100$, where $\mathrm{C}$ is the mycelial diameter of the control and $\mathrm{T}$ that of treated ones. The values given are the average of two replications. 
TABLE 2: ANTIFUNGAL ACTIVITY OF EXTRACTIVES OF ONION SEEDS, CHILLI SEEDS AND CHILLI PERICARPS AGAINST THE SPORE GERMINATION OF Cladosporium cucumerinum BY TLC BIOAUTOGRAPHY

\begin{tabular}{lcccc}
\hline Plant & Plant part & $\begin{array}{c}\text { Solvent used for } \\
\text { preparation of the } \\
\text { extractive }\end{array}$ & $\begin{array}{c}\text { Inhibition at a dose of 1.0 } \\
\text { mg (Direct bioautography } \\
\text { without prior elution) }\end{array}$ & $\begin{array}{c}\text { Rf value of inhibition } \\
\text { spot after elution with } \\
\text { EtOAc }\end{array}$ \\
\hline Onion (Allium cepa) & Seeds & Hexane & + & 0.49 \\
Onion (Allium cepa) & Seeds & Ethyl acetate & + & 0.49 \\
Onion (Allium cepa) & Seeds & Methanol & - & 0.79 \\
Chilli (Capsicum annuum) & Seeds & Hexane & ++ & 0.72 \\
Chilli (Capsicum annuum) & Seeds & Ethyl acetate & + & $0.62,0.72$ \\
Chilli (Capsicum annuum) & Seeds & Methanol & - & 0.72 (faint) \\
Chilli (Capsicum annuum) & Pericarps & Hexane & ++ & 0.72 \\
Chilli (Capsicum annuum) & Pericarps & Ethyl acetate & + & $0.62,0.72$ \\
Chilli (Capsicum annuum) & Pericarps & Methanol & - & 0.72 (faint) \\
\hline
\end{tabular}

Note: Observation on Cladosporium cucumerinum inhibition taken after an incubation of $4 \mathrm{~d}$; Thickness of the plate $=0.5 \mathrm{~mm}$; Diameter of the spot $1.2 \mathrm{~cm}$; + indicates inhibition; ++ indicates conspicuous inhibition; - indicates no inhibition

growth inhibition at a concentration of $0.5 \%$ level. Methanol extractives of Solanum viarum berries and ethyl acetate extractive of soybean leaves exhibited more than $20 \%$ mycelial growth inhibition at a concentration of $1.0 \%$ level. Hexane extractives of onion seeds, chilli seeds and chilli pericarps did not show activity against the mycelial growth of Colletotrichum gloeosporioides. The extractives of onion leaves, Albizia amara leaves, Bougainvillea spectabilis (green leaves, white bracts and pink bracts) and seeds of Gloriosa superba also did not show any significant activity.

Chemical nature of some antifungal compounds present in the presently investigated plants has been reported by earlier workers. An antimicrobial protein has already been isolated from onion seeds ${ }^{[3]}$. But it is doubtful whether the antifungal activity of ethyl acetate extractive presently reported is due to this protein since ethyl acetate extractive has only moderate polarity. Antifungal activity of capsaicin present in chilli has been established ${ }^{[4]}$. Antifungal activity of glycoalkaloids of Solanum viarum has been reported ${ }^{[5]}$. Antifungal activity of isoflavones ${ }^{[6]}$ in soybean leaves and glyceollins ${ }^{[7]}$ in infected soybean leaves also has been reported.

The results presented in Table 1 shows that the hexane extractives of onion seeds, chilli seeds and chilli pericarps do not show activity against the mycelial growth of Colletotrichum gloeosporioides even at a high concentration of $1 \%$ level. But Table 2 shows that these extractives show activity against the spore germination of Cladosporium cucumerinum on TLC plate. A similar trend was observed in the earlier studies reported from this institute in the cases of watermelon seeds and tomato seeds ${ }^{[8,9]}$. Most probably the fatty acid esters present in the hexane extractives of these vegetable seeds (watermelon, tomato, onion and chilli) have an antagonistic effect on the antifungal compounds as far as mycelial growth inhibition of Colletotrichum gloeosporioides is concerned. But this antagonistic effect of fatty acid esters is not effective in case of activity against the spore germination of Cladosporium cucumerinum. It is noteworthy that the ethyl acetate extractives of onion seeds, chilli seeds and chilli pericarps exhibit activity against the mycelial growth of Colletotrichum gloeosporioides and spore germination of Cladosporium cucumerinum on TLC plate. Direct bioautography of the methanol extractives of onion seeds, chilli seeds and chilli pericarps on TLC plate without prior elution with ethyl acetate did not exhibit any inhibition. This is most probably due to the presence of some carbohydrates or peptides present in the methanol extractives which promote the growth of Cladosporium cucumerinum. But if TLC plates spotted with methanol extractives are previously eluted with ethyl acetate and subsequently sprayed with the inoculum, inhibition zones are seen upon incubation.

\section{REFERENCES}

1. Nene YL, Thapliyal PN. Fungicides in plant disease control. $2^{\text {nd }}$ ed. Oxford and IBH Publications; 2002.

2. Homans AL, Fuchs A. Direct bioautography on thin-layer chromatograms as a method for detecting fungitoxic substances. J Chromatogr 1970;51:327-9.

3. Cammue BP, Thevissen K, Hendriks M, Eggermont K, Goderis $\mathrm{IJ}$, Proost $\mathrm{P}$, et al. A potent antimicrobial protein from onion 
seeds showing sequence homology to plant lipid transfer proteins. Plant Physiol 1995;109(2):445-55.

4. Fieira C, Oliveira F, Calegari RP, Machado A, Coelho AR. In vitro and in vivo antifungal activity of natural inhibitors against Penicillium expansum. Food Sci Technol 2013;33:40-6.

5. Cipollini ML, Levey DJ. Antifungal activity of Solanum fruit glycoalkaloids: implications for frugivory and seed dispersal. Ecology 1997;78(3):799-809.

6. Kim HJ, Suh HJ, Lee CH, Kim JH, Kang SC, Park S, et al. An- tifungal activity of glyceollins isolated from soybean elicited with Aspergillus sojae. J Agric Food Chem 2010;58(17):94837.

7. Naim M, Gestetner B, Zilkah S, Birk Y, Bondi A. Soybean isoflavones. Characterization, determination, and antifungal activity. J Agri Food Chem 1974;22(5):806-10.

8. Nidiry EJ. Antifungal activity of watermelon seed extracts. Fitoterapia (Milano). 1998;69(5):466-8.

9. Nidiry ES. Antifungal activity of tomato seed extracts. Fitoterapia. 1999;70(2):181-3. 